Dept. of Food Control,

Fac. Vet. Med. Zagazig Univ.,

Head of Dept. Prof. Dr. H.M. Al-Ashmawy.

\title{
THERMAL INACTIVATION OF YERSINIA \\ ENTEROCOLITICA IN MILK AND ITS SURVIVAL IN YOGHURT
}

(With 2 Tables)

By

S.R. EL-GMIEY; A.A. EL-EBEEDY

A.M. AL-ASHMAWY and

A.M. EL-GAMEL

(Received at 9/6/1994)

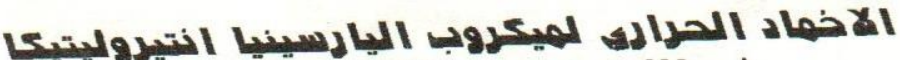

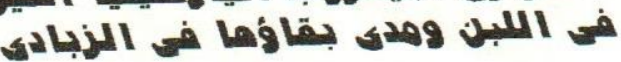

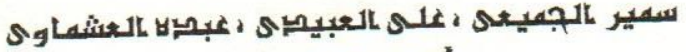

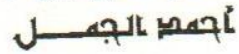

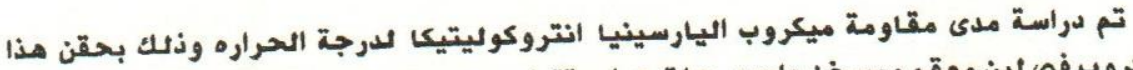

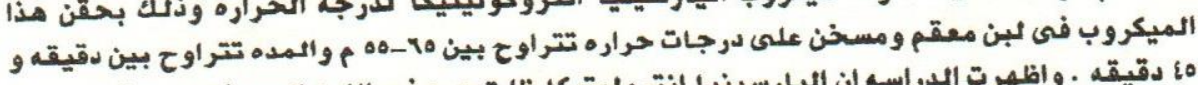

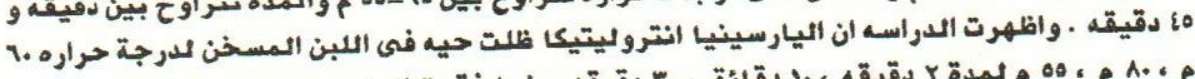

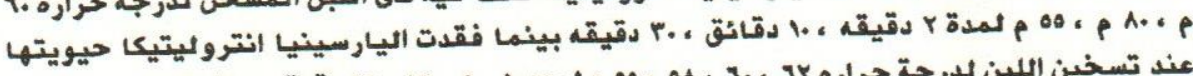

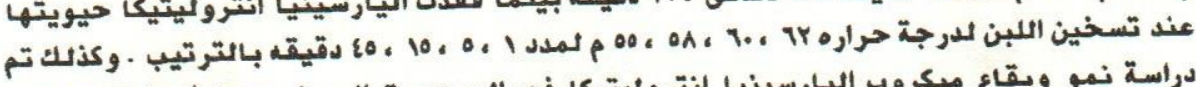

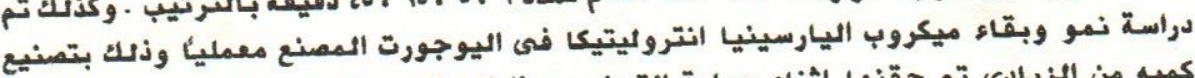

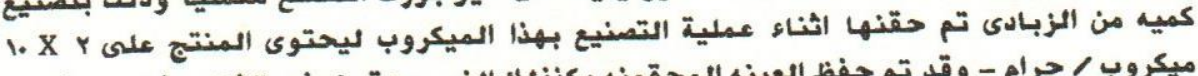

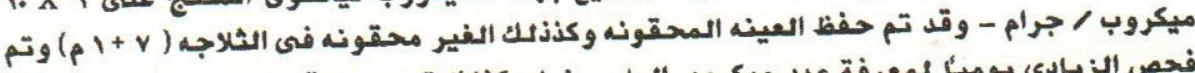

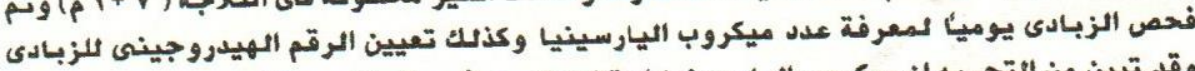

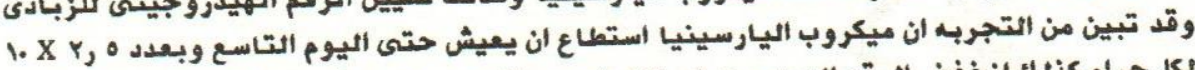

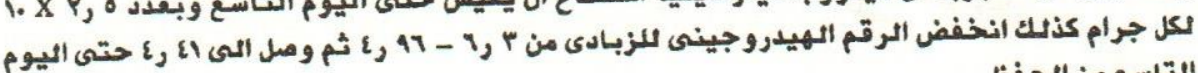

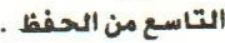

Assiut Vet. Med. J. Vol. 31, No 62, July, 1994. 


\section{SUMMARY}

Thermal inactivation of Yersinia enterocolitica in milk revealed that Yersinia enterocolitica was destroyed at $62^{\circ} \mathrm{C}$ after one minute of exposure, at $60^{\circ} \mathrm{C}$. The thermal resistance starts to develop which increases with shorten the time of exposure as growth of yersinia enterocolitica was very good/one minute and deminished to be non detectable/five minute. The thermal death time was 45 minute at $55^{\circ} \mathrm{C}$. Yersinia enterocolitica could survive in artifically contaminated yoghurt stored at refrigeration temperature $\left(7: 1^{\circ} \mathrm{C}\right)$ for 9 days.

Keywords: Y. enterocolitica, survival, milk \& yoghurt

\section{INTRODUCTION}

Pathogenic bacteria in milk have been a matter of public health concern since they early days of dairy industry.

Yersinia enterocolitica has the distinction of surviving and multiplying in food held at refrigation temperature, therefore milk and its products contaminated initially with even low levels of this organism may serve not only as a vehicle but also as a medium for its proliferation (STERN et al. , 1980b).

Milk and milk products have been incriminated in several outbreaks of yersiniosis due to the psychrotrophic nature of yersinia enterocolitica is combined with increasing use of refrigeration in food preservation.

\section{MATERIAL AND METHODS}

Thermal inactivation of Y. enterocolitica in milk:

Two hundred raw milk samples got from cooled bulk tank $\left(4^{\circ} \mathrm{C}\right)$ were distributed into twenty sealed test tubes $(10 \mathrm{ml})$. All milk samples were sterilized by autoclaving at $121^{\circ} \mathrm{C}$ for 10 min., then cooled to $30^{\circ} \mathrm{C}$. Fourteen samples were artificially inoculated with Yersinia enterocolitica culture to have a density of $10^{9}$ cells/ml. The tested and control tubes were placed in a water bath and subjected for different temperatures, $65^{\circ} \mathrm{C}, 62^{\circ} \mathrm{C}$ for one min, $60^{\circ} \mathrm{C}$ for $1,2,3 \mathrm{~min}, 58^{\circ}$ for one, 5,10,15 min. and $55^{\circ}$ for $5,15,30,45$, min.

Assiut Vet. Med. J. Vo1. 31 No. 62, July 1994. 
The contaminated milk level in test tubes were below that in the water bath and the temperature inside the piolt tube was determined for detection of Yersinia in artificially contaminated milk, the inoculated tubes were cooled direclty in ice water and the detection of Yersinia was done.

\section{Survival of Yersinia enterocolitica in yoghurt:} Preperation of inoculum:

Manufacture of yoghurt ( $A L-A S H M A W Y, 1990)$ Two raw milk samples got from Yersinia enterocolitica free dairy cows were heated at $90^{\circ} \mathrm{C}$ for $30 \mathrm{~min}$, then cooled to about $40^{\circ} \mathrm{C}$ and inoculated with $2 \%$ of yoghurt starter cultures. Immediately after adding the starter, the test sample were incoculated with Yersinia enterocolitica to provide $10^{6}$ cells $/ \mathrm{ml}$.

The artificially contaminated and control samples were incubated at $40^{\circ} \mathrm{C}$ till curdling then stored in refrigerator (temp. $7: 1^{\circ} \mathrm{C}$ ) for 9 days.

\section{Sampling .}

The inoculated yoghurt curd was examined for Yersinia enterocolitica, while control yoghurt curd was used for measuring $\mathrm{pH}$ values samples were taken from milk after innoculation and from prepared yoghurt daily up to 9 days.

\section{Estimation of yersinia enterocolitica in yoghurt:}

The techhique applied was described by APHA (1985). Eleven grams of the prepared yoghurt samples were added to $99 \mathrm{ml}$ of sterile distilled water and thoroughly mixed to make a dilution $1 / 10$, from which 10 fold serial dilutions were prepared (MARTH, 1978). $0.1 \mathrm{ml}$ of previously prepared serial dilutions was plated on to CIN medium and incubated at $28^{\circ} \mathrm{C}$ for 24 hours.

Plates showed countable colonies were selected and counted for Yersinia per $\mathrm{g}$.

The suspected colonies were picked up, purified and identified.

$\mathrm{pH}$ determiation by using $\mathrm{pH}$ meter:

$\mathrm{pH}$ of milk sample was measured directly by using $\mathrm{pH}$ meter (Jenco, Model 609). Control yoghurt samples (10 grams) were homogenized with $90 \mathrm{ml}$ of distilled water by using blender and the electrode was immersed into the yoghurt emlusion. The results of $\mathrm{pH}$ were registered.

Assiut Vet. Med. J. Vol. 31 No. 62, July 1994. 
YERSINIA ENTEROCOLITCA MILK, URVIVAL \& YOGHURT

\section{RESULTS}

Table (1) Thermal inactivation of Yersinia enterocolitica in milk

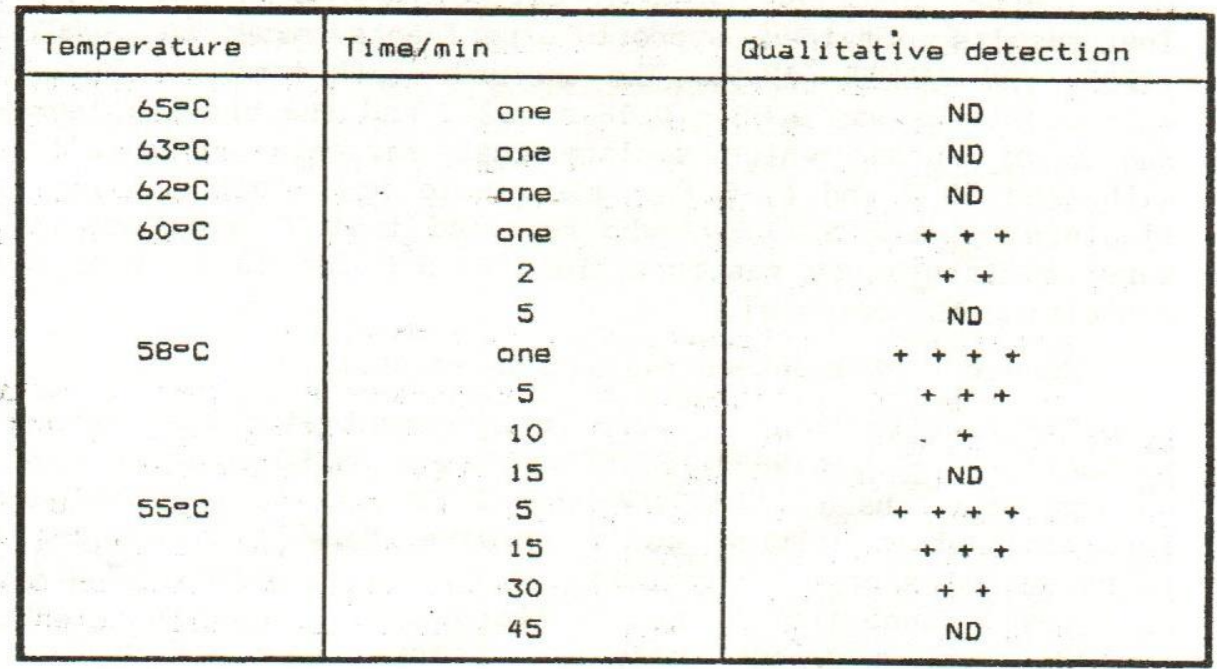

\section{++++ Excellent growth}

+ Good growth.

ND Not detected.
Very good growth. Fairly growth.

Table (2) Growth and survival of Yersenia enterocolitica in yoghurt stored at $(7: 10 \mathrm{C})$

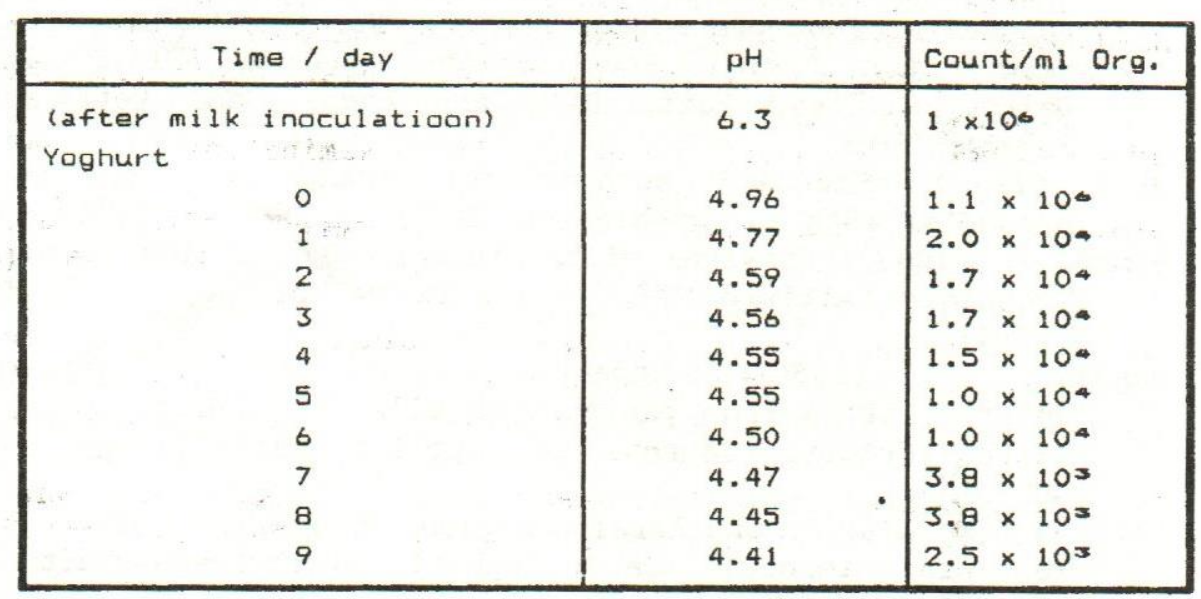

Assiut Vet. Med. J. Vo1. 31 No. 62, July 1994. 


\section{S.R. EL-GMIEY et $\underline{\text { al }}$}

\section{DISCUSSION}

Thermal inactivation of $\mathrm{Y}$. enterocolitica in milk:

The results obtained support experiments made by SORGVIST (1989) and WALKER (1989). The thermal death time for Yersenia enterocolitica was $0.09-0.18$ at $62^{\circ} \mathrm{C}$ and the observations of the first author which declare that Yersenia enterocolitica withstand $58^{\circ} \mathrm{C}$ and $60^{\circ} \mathrm{C}$ for one minute while differ from the findings of HUGHES (1980) who reported that Y. enterocolitica survived laboratory pasteurzation $\left(63.5^{\circ} \mathrm{C}\right.$ for $\left.30 \mathrm{~min}\right)$ of milk containing $10^{8}$ cells $/ \mathrm{ml}$.

\section{Survival of Y.enterocolitica in yoghurt:}

The results obtained were in agreement with that reported by Mant is et al., (1982), BIMET (1983 and AHMED et al., (1986). On the other hand, SLACCHEV and GOGOV (1983) reported that Yersenia enterocolitica could survive for 24 hours during refrigerated storge of yoghurt. Other investigators (MATTA et al., 1991) found that Yersenia enterocolitica survived pH 3.87 for 48 hours in yoghurt made from sterile milk and stored at $5-7^{\circ} \mathrm{C}$.

Isolation of Yersenia enterocolitica from yoghurt was reported by UMOH et al., (1984).

\section{REFERENCES}

Ahmed, A.A.H., Moustafa, K.M. and E1-Bassiony, T.A. (1986): Growth and survival of Yersinia enterocolitico in Yoghurt. Journal of food protection Vol. 49, No. 12, 983-985.

Al-Ashmawy, A.M. (1990): Food Hygiene Handbook, Fluid milk, Dairy products, Fats, 011 s and Eggs. Fac. Vet. Med. Zagazig Univ.

Apha (1985): Standard methods for examination of dairy products. 15 th ed. washington, D.C.

Bimet, F. (1983): Survival of Yersinia enterocolitica in milk. Technique Laitiere 977, 43-45. Dairy Sci. Abst. 46, (6) (1984).

Hughes, D. (1980): Repeated isolation of Yersinia enterocolitica from pasteurized milk in holding vat at a dairy factory. Journal of Applied Bacteriology. 48, 303-385.

Matis A., Koidis, P. and Karaioannoglou, P. (1982): Survival of Yersinia enterocolitica in Yoghurt. Milchwissenschaft 37, 654-656.

Assiut Vet. Med. J. Vol. 31 No. 62, July 1994. 
Marth, E.H. (1978): Standard methods for the
dairy products.

Matta, H. ; Kalra washington, D.C. ed American examination of , H.; Kalra, M.S. and Singh, A. (1991). pathogenic bacteria in Yoghurt $A$. (1991): Survival of Technol. Col. 28, No 4, 240-243. and dahi. J. Fd. Sci

Slavchev, enterocolitica in Bulgarian (1983): Survival of Yersinia milk. Veterirwrnomeditsinsk yoghurt and vita cultures Abst. Vol. 46, No. (6), (1984).

Sorgvist, S. (1989). (6), (1984).

Yersinia strains by thresistance of Campylobacter and Bcteriology 67, 543-549.

Stern, N.J.; Pierson, M43-549. competitive nature of Yersinia A.W. (1980b): Growth and milk. Journal of food science

Umoh, V.J.; Dangana, $A$. and Umoh Vol. 45, 72-74. Yersinia enterocolitica form, J.U. (1984): Isolation of Zaria, Nigeria. Int. J. Zoon. 11. 223-228 milk products in

Walker, S.J. (1989): Yersinia. Zoon. 11. 223-228.

Course Surey University Department Food Microbiology Campden Food and Drink Researtment of Micicrobiology. Campdenn, Glos. Gl. 55 6LD. 